DOI: 10.20472/IAC.2019.051.009

\author{
JULIA FODOR \\ Károli Gáspár University , Hungary
}

\title{
ROE V. WADE AND THE APPOINTMENT OF JUSTICE KAVANAUGH TO THE SUPREME COURT
}

\begin{abstract}
:
While Roe v. Wade (1973) is one of the landmark court cases of the 20th century, Norma Nelson McCorvey, the woman behind the case who has been catapulted to world "fame" as Jane Roe, the plaintiff of Roe v. Wade, is much less well-known. Norma, a victim of abuse throughout her childhood, was struggling with addictions of alcohol and drugs. By age 21 she had given birth twice, and was pregnant for the third time. She was desperate to have an abortion, so she lied about having been raped in the hope that it would secure her the right to an abortion in the State of Texas where otherwise she would have been denied that choice. The Supreme Court's verdict came too late for Jane Roe. She never got that abortion or any abortion for that matter in her lifetime, yet her name is inseparably coupled with women's right to abortion in America. The US Supreme Court by a 7:2 ruling decided that state laws that ban abortion are unconstitutional. Could that decision be actually overturned if the number of conservative justices outnumbered that of the liberal justices? In my paper I intend to discuss how Jane Roe's change of views on abortion and her request for a retrial of her case in 2004 by the US Supreme Court foreshadowed some of the most significant changes in the pro-life/pro-choice landscape. I will also touch upon the dynamics behind the fact that 45 years after the legalization of abortion in America Roe v. Wade was the most frequently mentioned case during the Senate Judiciary Committee's Brett Kavanaugh hearings in 2018. Justice Kennedy, whose place on the Supreme Court was filled by Brett Kavanaugh, had been a swing vote on social issues, mostly voting in favor of abortion rights. President Trump, on the other hand, has "long vowed to appoint justices who would reverse Roe and allow the states to determine whether abortion should be legal". Throughout the hearings, Kavanaugh would consistently decline to confirm or deny if he would be willing to reverse Roe v. Wade.
\end{abstract}

\section{Keywords:}

\author{
Abortion rights \\ Women's rights \\ Supreme Court \\ Roe v. Wade \\ Appointment of Kavanaugh
}

JEL Classification: D72, D74 